\title{
Fylgikvillar blaðnámsaðgerða við lungnakrabbameini á Íslandi 1999-2008
}

Rut Skúladóttir ${ }^{1}$ læknanemi

Guðrún Nína
Óskarsdóttir $^{1}$ læknanemi

Helgi J. Ísaksson ${ }^{2}$ meinafræðingur

Steinn Jónsson ${ }^{1,3}$ lungnalæknir

Húnbogi Porsteinsson ${ }^{1}$

læknanemi

Tómas

Guðbjartsson ${ }^{1,4}$

brjóstholsskurðlæknir

Lykilorð: lungnakrabbamein, skurðaðgerðir, blađnám, ábendingar, fylgikvillar, skurðdauði.

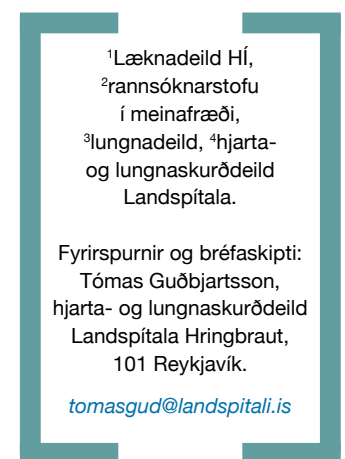

\section{Ágrip}

Inngangur: Lungnakrabbamein er annað algengasta krabbamein á Íslandi og pað sem dregur flesta til dauða. Skurðaðgerð er helsta meðferðin og langoftast er beitt blaðnámi. Markmið pessarar rannsóknar var að kanna ábendingar og snemmkomna fylgikvilla blaðnáms á Íslandi.

Efniviður og aðferðir: 213 sjúklingar sem gengust undir blaðnám vegna lungnakrabbameins á árunum 1999-2008. Kannaðar voru ábendingar, fylgikvillar, æxlisgerð og TNM-stigun. Aðhvarfsgreining var notuð til að meta áhættupætti fylgikvilla.

Niðurstöður: 85 sjúklingar (40\%) greindust fyrir tilviljun en aðrir vegna einkenna sjúkdómsins. Kirtilmyndandi krabbamein (62\%) og flögupekjukrabbamein $(29,1 \%)$ voru algengust. Flestir greindust á stigi I $(59,6 \%)$ og stigi II $(17,8 \%)$, $7 \%$ á stigi IIIA og $14,8 \%$ á stigum IIIB-IV. Miðmætisspeglun var gerð hjá 13,6\% sjúklinga fyrir blaðnám. Meðalaðgerðartími var 128 mínútur og blæðing í aðgerð $580 \mathrm{ml}$. Sextán sjúklingar (7,5\%) fengu alvarlega fylgikvilla og 36 (17\%) minniháttar fylgikvilla, oftast lungnabólgu (6,1\%) og gáttatif/ flökt (6,1\%). Tólf sjúklingar purftu enduraðgerð, tveir vegna fleiðruholssýkingar og einn vegna berkjufleiðrufistils. Eldri sjúklingar með hátt ASAskor og langa reykingasögu voru í aukinni hættu á að fá fylgikvilla eftir aðgerð. Legutími eftir aðgerð var 10 dagar (miðgildi). Enginn sjúklingur lést $\leq 30$ daga frá aðgerð en tveir $(0,9 \%) \leq 90$ daga frá aðgerð.

Ályktun: Skammtímaárangur blaðnámsaðgerða vegna lungnakrabbameins er góður hér á landi samanborið við aðrar rannsóknir.

\section{Inngangur}

Lungnakrabbamein er annað algengasta krabbamein á Íslandi og pað krabbamein sem dregur flesta til dauða. ${ }^{1}$ Árlega greinast hér á landi um 130 einstaklingar en aldursstaðlað nýgengi á árunum 2002-2006 var 31,4/100.000 hjá körlum og 30/100.000 hjá konum. ${ }^{2}$

Helsta meðferð til lækningar er skurðaðgerð og á hún fyrst og fremst við um staðbundið lungnakrabbamein önnur en smáfrumukrabbamein, á stigum I og II og í völdum tilfellum á stigi IIIA. 3, 4 Á pessu eru einstaka undantekningar, og pá helst pegar um er að ræða stök meinvörp 1 heila eða nýrnahettu. ${ }^{5}$ Í Evrópu hefur hlutfall sjúklinga sem gangast undir skurðaðgerð vegna lungnakrabbameins verið lægra (10-20\%), en víða í Bandaríkjunum par sem pað nálgast 30\%. ${ }^{6}$ Stór hluti sjúklinga læknast pó ekki af sjúkdómnum prátt fyrir skurðaðgerð, til dæmis eru aðeins tveir af hverjum premur sjúklingum á stigi I lifandi fimm árum frá aðgerð, ${ }^{7,8}$ og eru flest dauðsföll vegna fjarmeinvarpa. ${ }^{8}$

Hefðbundin skurðaðgerð við lungnakrabbameini er blaðnám. ${ }^{1}$ Komist er að lunganu á milli rifja og lungnablaðið fjarlægt í heild sinni ásamt eitlum í lungnarót. Einnig eru tekin sýni úr miðmætiseitlum til stigunar. Fylgikvillar eru tiltölulega algengir eftir blaðnám, ${ }^{9,} 10$ enda margir sjúklinganna með reykingatengda sjúkdóma, svo sem langvinna lungnateppu og kransæðasjúkdóma. Ef lungnastarfsemi sjúklings leyfir ekki blaðnám er mögulegt að framkvæma fleyg-eða geiraskurð (wedge/segmentectomy) par sem aðeins hluti lungnablaðsins er fjarlægður., 4 Ókostur við pessar aðgerðir er að tíðni endurtekins krabbameins er prefalt hærri en við blaðnám. ${ }^{11}$ Pví er leitast við að fjarlægja allt lungnablaðið sé pað hægt. Brottnám alls lungans er pó aðeins gert í undantekningartilfellum við stór og miðlæg æxli, enda fylgikvillar lungnabrottnáms helmingi algengari en eftir blaðnám. ${ }^{12}$ Árangur skurðaðgerða við lungnakrabbameini hefur lítið verið rannsakaður á Íslandi. Pví voru í pessari rannsókn kannaðar ábendingar, stigun og fylgikvillar við blaðnámsaðgerðir á Íslandi á 10 ára tímabili.

\section{Efniviður og aðferð̈ir}

Rannsóknin er afturskyggn og nær til 213 sjúklinga sem gengust undir blaðnám frá 1. janúar 1999 til 31. desember 2008 við lungnakrabbameini 
öðru en smáfrumukrabbameini. Einum sjúklingi var sleppt par sem gögn vantaði. Tveimur æxlum sem innihéldu smáfrumukrabbamein var sleppt en einnig sjúklingum með krabbalíki (carcinoid) og stórfrumukrabbamein af taugauppruna (large cell neuroendocrine).

Gögn voru fengin úr tveimur aðskildum skrám, annars vegar rafrænni aðgerðarskrá Landspítala og hins vegar úr gagnagrunni rannsóknarstofu Landspítala í meinafræði. Upplýsingar um heildarfjölda greindra tilfella af lungnakrabbameini önnur en smáfrumukrabbamein voru fengnar úr Krabbameinsskrá Krabbameinsfélags Íslands og klínískar upplýsingar úr sjúkráskrám, par á meðal úr rafrænni sjúkraskrá Landspítala. Einnig var stuðst við meinafræðisvör. Vefjasýni voru skoðuð að nýju pegar fullnægjandi upplýsingar vantaði í meinafræðisvörum (11 tilfelli). Úr sjúkraskrám voru skráðar rúmlega 80 breytur í tölvuforritið Excel, meðal annars einkenni, áhættupættir og ástand sjúklinga fyrir aðgerð, fylgikvillar í og eftir aðgerð, legutími, stærð æxlis og stigun í aðgerð (pTNM), endurkoma sjúkdóms og lífshorfur. Einnig var skoðað hversu margir létust innan við 90 daga frá aðgerð. Skráð var ASA (American Society of Anesthesiologists) flokkun sjúklinga sem metur heilsufar og ástand sjúklings fyrir aðgerð. ${ }^{13}$ Skráð voru gildi úr öndunarmælingum, bæði FVC (forced vital capacity) og $\mathrm{FEV}_{1}$ (forced expiratory volume in 1 second) og hvort pessi gildi væru undir eða yfir 80\% af spáðum viðmiðunargildum.

Æxlin voru stiguð samkvæmt TMN stigunarkerfi fyrir lungnakrabbamein ${ }^{8}$ og var skráð vefjagerð, gráða frumuafbrigða, mesta pvermál og hvort skurðbrúnir væru án æxlisvaxtar. Stigun miðast við upplýsingar sem lágu fyrir eftir vefjaskoðun sýnis úr aðgerð (pTNM). Sjúklingar sem greindir voru með fjarmeinvörp innan priggja

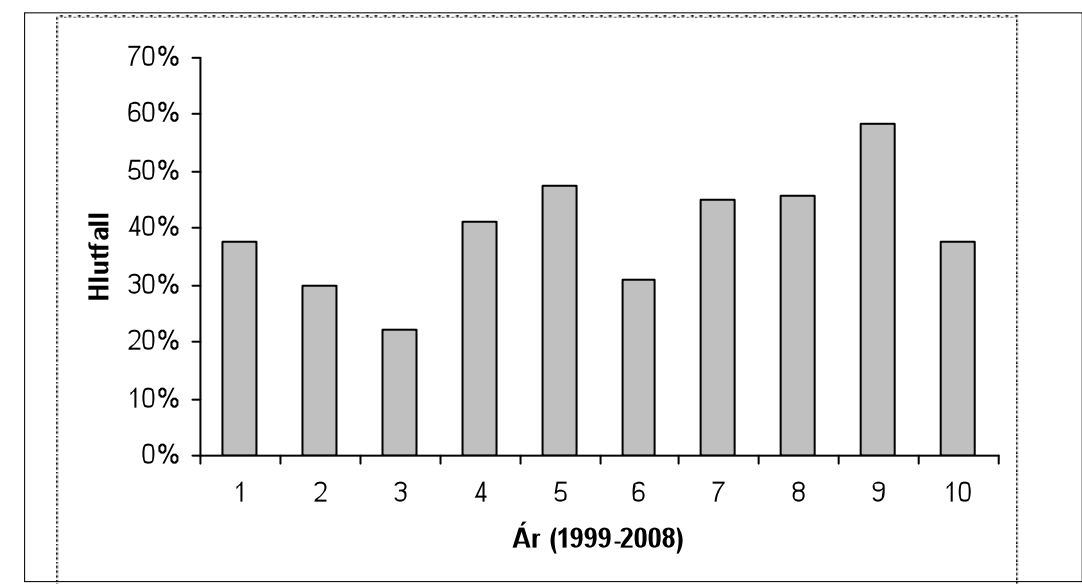

Mynd 1. Hlutfall sjúklinga sem greindust án einkenna lungnakrabbameins (tilviljanagreining) og gengust undir lungnabladnám á Íslandi frá 1999 til 2008. mánaða frá aðgerð voru stigaðir með útbreiddan sjúkdóm (stig IV). Sjúklingar voru stigaðir fyrir aðgerð með hjálp tölvusneiðmynda af brjóstholi og efri hluta kviðarhols og einnig af höfði ef ástæða pótti til. Stór hluti sjúklinga fór í berkjuspeglun (75,1\%). Gerð var miðmætisspeglun í 13,6\% tilfella, par af fóru 18 sjúklingar $(8,5 \%)$ í slíka speglun í sömu aðgerð og blaðnámið. Skurðdauði (operative mortality) var skilgreindur sem andlát innan 30 daga frá aðgerð. Einnig var skoðað hversu margir létust innan 90 daga frá aðgerð.

Aðgerðirnar voru framkvæmdar af sex skurðlæknum. Prír peirra framkvæmdu stærstan hluta aðgerða, eða á bilinu 50-62 aðgerðir hver, en hinir á bilinu 10-25 aðgerðir. Sjúklingar voru svæfðir með tvíopa berkjurennu og pannig fellt saman pað lunga sem gerð var aðgerð á. Sjúklingar voru hafðir í $90^{\circ}$ hliðarlegu og brjóstholið opnað með aftari/hliðar brjóstholsskurði undir fjórða eða fimmta rifi. Á síðari hluta rannsóknartímabilsins (frá 2005) var oftar gerður fremri/hliðar brjóstholsskurður (anterolateral thoracotomy) undir sömu rifjabilum með sjúkling í $45^{\circ}$ hliðarlegu. Í aðgerðunum var heftað eða saumað fyrir berkju og slag- og bláæðar til pess blaðs sem fjarlægt var. Miðmætiseitlar voru ekki stigaðir í aðgerð með skipulögðum hætti fyrr en eftir 2005. Í lok aðgerðar var komið fyrir tveimur brjóstholskerum sem sjúklingar höfðu eftir pörfum, allt frá einum degi og upp í 77 daga. Sjúklingar voru flestir fluttir á vöknun eftir aðgerð. Vegna vandamála sem upp komu í aðgerð eða til eftirlits var 31 sjúklingur fluttur á gjörgæslu eftir aðgerð.

Tölfræðilegir útreikningar voru gerðir í tölvuforritunum Excel og R (útgáfa 2.8.1) og kíkvaðrat og t-próf notuð við samanburð á hópum. Gerð var fjölpátta aðhvarfsgreining (logistic regression analysis) og fylgikvillum skipt í minni- og meiriháttar fylgikvilla ${ }^{12}$ (sjá síðar, tafla IV). Fyrir spábreyturnar minniháttar fylgikvilla, meiriháttar fylgikvilla og alla fylgikvilla saman voru upphaflega gerð spálíkön sem innihéldu pær forspárbreytur sem safnað var. Síðan var gerð prepaútfelling (stepwise backwards logistic regression) par sem forspárbreytur voru felldar úr líkaninu par til besta spálíkanið stóð eftir. Рað líkan var síðan notað til að reikna út áhættuhlutfall (OR, odds ratio) og miðast tölfræðileg marktækni við p-gildi $<0,05$ og eru gefin upp 95\% öryggisbil (CI).

Öll tilskilin leyfi lágu fyrir áður en rannsóknin hófst, frá Persónuvernd, Vísindasiðanefnd og framkvæmdastjóra lækninga á Landspítala. 


\section{Niơurstöour}

Samkvæmt Krabbameinsskrá Krabbameinsfélags Íslands greindust á rannsóknartímabilinu alls 1047 einstaklingar með lungnakrabbamein önnur en smáfrumukrabbamein (ÖES). Í töflu I má sjá hlutfall peirra sjúklinga sem gengust undir lungnablaðnám af öllum greindum tilfellum á hverju ári. Árlegur fjöldi aðgerða var á bilinu 16-29 og jókst fjöldi aðgerða marktækt eftir pví sem leið á rannsóknartímabilið $(\mathrm{p}=0,038)$. Aukinn fjöldi aðgerða sem hlutfall greindra tilfella var pó ekki marktækur $(p=0,065)$.

Alls greindust 85 sjúklingar (40\%) fyrir tilviljun (mynd 1), oftast vegna myndrannsókna sem gerðar voru vegna annarra sjúkdóma eða slysa. Tilhneiging til aukningar í tilviljanagreiningu sást á síðari hluta rannsóknartímabilsins en munurinn var ekki marktækur $(\mathrm{p}=0,098)$. Stærstur hluti $(60 \%)$ sjúklinga greindist vegna einkenna og eru pau helstu sundurliðuð í töflu II.

Alls gengust $29(13,6 \%)$ sjúklingar undir miðmætisspeglun fyrir aðgerðina, par af 18 (8,5\%) í sömu aðgerð. Aðgerðartími (skin-to-skin) var að meðaltali 128 mínútur (bil 45-360) og var blæðing í aðgerð að meðaltali $580 \mathrm{ml}$ (bil 100$4000 \mathrm{ml}$ ). Alls blæddi meira en $1000 \mathrm{ml}$ í aðgerð hjá 23 sjúklingum, oftast vegna blæðingar frá lungnaslagæð eða lungnabláæð.

Alls voru 132 sjúklingar (62\%) með kirtilmyndandi krabbamein, $62 \quad(29,1 \%)$ með flögupekjukrabbamein og $9(4,2 \%)$ með stórfrumukrabbamein. Tíu sjúklingar $(4,7 \%)$ reyndust með aðrar gerðir lungnakrabbameins (ÖES), par af voru átta $(3,7 \%)$ með kirtilmyndandi flögupekjukrabbamein (adenosquamous carcinoma), einn $(0,5 \%)$ með blöðrukirtilmyndandi krabbamein (adenoid cystic carcinoma) og annar $(0,5 \%)$ með óproskað krabbamein af pekjuuppruna (undifferentiated carcinoma). Tveir sjúklingar voru fyrir aðgerð greindir með flögupekjukrabbamein við berkjuspeglun en reyndust við smásjárskoðun á sýni úr aðgerð vera með setkrabbamein (carcinoma in situ, stig 0).

Algengast var að æxlin væru meðalvel proskuð (41,3\%), par næst illa proskuð (33,8\%) og 18,8\% voru vel proskuð. Tíu (4,7\%) æxli voru óproskuð (anaplastic). Gráðun var ekki greinanleg í premur $(1,4 \%)$ tilvikum, meðal annars hjá sjúklingi með Pancoast-æxli sem fór í geislameðferð fyrir aðgerð.

Meðalstærð æxlanna var 3,7 cm $\pm 2,1$ en minnsta æxlið var 0,2 cm og pað stærsta $19 \mathrm{~cm}$. Æxlisvöxtur sást í skurðbrún 14 sjúklinga við vefjaskoðun og fengu átta peirra geisla- og/eða lyfjameðferð í kjölfarið. Hinir sex fengu enga viðbótarmeðferð og létust tveir peirra stuttu eftir aðgerðina. Annar peirra var með setkrabbamein
Tafla I. Hlutfall sjúklinga sem gengust undir lungnablaðnám af öllum sem greindust með lungnakrabbamein (smáfrumukrabbamein undanskilin) á Íslandi 1999-2008.

\begin{tabular}{cccc}
\hline Ár & $\begin{array}{c}\text { Fjöldi greindra } \\
\text { lungnakrabbameina annarra } \\
\text { en smáfrumukrabbameina }\end{array}$ & Fjöldi aðgerða & Hlutfall (\%) \\
\hline 1999 & 116 & 16 & 13,8 \\
\hline 2000 & 124 & 20 & 16,1 \\
\hline 2001 & 108 & 19 & 17,6 \\
\hline 2002 & 96 & 16 & 16,7 \\
\hline 2003 & 126 & 21 & 16,7 \\
\hline 2004 & 119 & 29 & 24,4 \\
\hline 2005 & 117 & 20 & 17,1 \\
\hline 2006 & 120 & 24 & 20,0 \\
\hline 2007 & 121 & 24 & 19,8 \\
\hline 2008 & $* *$ & 24 & $*$ \\
\hline
\end{tabular}

* lungnakrabbamein önnur en smáfrumukrabbamein

** upplýsingar vantar

Tafla II. Einkenni 128 sjúklinga (tilviljanagreindum sleppt) sem gengust undir lungnablađnám á Íslandi 1999-2008. Sjúklingar geta haft fleiri en eitt einkenni samtímis. Gefinn er upp fjöldi sjúklinga og prósentur í sviga.

\begin{tabular}{ll}
\hline Einkenni & $\mathrm{n}(\%)$ \\
\hline Hósti & $78(60,9)$ \\
\hline Hósti með uppgang & $40(30,3)$ \\
\hline Brjóstverkur & $41(32,0)$ \\
\hline Blóðhósti & $14(10,9)$ \\
\hline Mæði & $50(39,1)$ \\
\hline Pyngdartap & $32(25,0)$ \\
\hline Hiti & $18(14,1)$ \\
\hline Lungnabólga & $30(23,4)$
\end{tabular}

af pekjufrumuuppruna (squamous carcinoma in situ) og var pví ekki talinn purfa viðbótarmeðferð en hinn sjúklingurinn lést ári eftir aðgerð.

Flestir sjúklinganna $(59,6 \%)$ greindust á stigi I, en $17,8 \%$ á II, og 7\% á stigi IIIA. Stigun hélst tiltölulega óbreytt á milli ára. Prettán sjúklingar greindust á stigi IIIB. Flestir peirra voru með tvö eða fleiri æxli í sama lungnablaði. Ellefu sjúklingar voru á stigi IV, par af voru prír greindir með stakt heilameinvarp áður en peir gengust undir blaðnám. Prír sjúklingar greindust með meinvarp í aðgerð og fimm sjúklingar innan priggja mánaða frá aðgerð, flestir með meinvörp í heila.

Miðgildi legutíma eftir aðgerð var 10 dagar, eða allt frá tveimur og upp í 106 daga. Alls lágu 30 sjúklingar (14,5\%) á gjörgæslu eftir aðgerð, par af 20 peirra í tæpan sólarhring, oftast til eftirlits vegna hjarta-, lungna- eða nýrnasjúkdóma. Ellefu (5,2\%) sjúklingar lágu lengur en sólarhring á gjörgæslu, en sá sem lá par lengst var í 75 daga. Átta (3,8\%) sjúklingar voru ekki vaktir á skurðstofu og voru fluttir á gjörgæslu í öndunarvél, par sem peir voru frá einum og upp í 74 daga í öndunarvél. 
Tafla III. Upplýsingar um aldur, kyn og áhættupætti 213 sjúklinga sem gengust undir lungnablaðnám á Íslandi 1999-2008. Gefinn er upp fjöldi sjúklinga og prósentur í sviga nema annað sé tekið fram.

\begin{tabular}{|c|c|}
\hline Upplýsingar & $\mathrm{n}(\%)$ \\
\hline Fjöldi & 213 \\
\hline Karlar & $108(50,7)$ \\
\hline Meðalaldur (ár, bil) & $66,9(37-89)$ \\
\hline Saga um reykingar & $205(96,2)$ \\
\hline Reykir* & $144(67,6)$ \\
\hline Pakkaár (miðgildi) & 42,1 \\
\hline Langvinnur lungnasjúkdómur & $60(28,2)$ \\
\hline Kransæðasjúkdómur & $55(25,8)$ \\
\hline Hjartsláttaróregla & $36(16,9)$ \\
\hline FVC $<80 \%$ af viðmiðunargildi & $44(20,7)$ \\
\hline FEV $1<80 \%$ af viðmiðunargildi & $78(36,6)$ \\
\hline \multicolumn{2}{|l|}{$\mathrm{ASA}^{\star \star}$ flokkun } \\
\hline 1 & $1(0,5)$ \\
\hline 2 & $92(43,2)$ \\
\hline 3 & $114(53,5)$ \\
\hline 4 & $6(2,8)$ \\
\hline $\begin{array}{l}{ }^{*} \text { `Sjúklingur hefur reykt innan } 5 \text { ára } \\
{ }^{* *} \text { American society of Anesthesiol }\end{array}$ & \\
\hline
\end{tabular}

Tveir sjúklingar fengu geislameðferð fyrir aðgerð og prír krabbameinslyfjameðferð (neoadjuvant). Einn peirra var með Pancoast-æxli sem fékk bæði geisla- og lyfjameðferð fyrir aðgerð. Annar sjúklingur var með $11 \mathrm{~cm}$ stórt æxli og fékk geislameðferð fyrir aðgerð. Tveir sjúklingar með fjarmeinvörp fóru í lyfjameðferð fyrir aðgerð. Annar peirra var talinn hafa útbreiddan sjúkdóm í lifur og pví óskurðtækur. Síðar kom í ljós að um góðkynja blöðrur í lifur var að ræða og var hann pá tekinn beint í lungnablaðnám. Hinn sjúklingurinn sem fékk lyfjameðferð var talinn hafa meinvörp í beinum og var pví gefin meðferð með krabbameinslyfjum. Síðar kom í ljós að meinvörp voru ekki til staðar og var hann pá tekinn í blaðnámsaðgerð.

Lyfjameðferð eftir skurðaðgerð (adjuvant) var gefin 26 sjúklingum (12,2\%), níu fengu geislameðferð eingöngu eftir aðgerð og fimm báðar meðferðirnar. Flestir pessara sjúklinga voru á stigum IIIA, IIIB eða IV eða höfðu æxlisvöxt 1 skurðbrúnum.

Upplýsingar um sjúklinga eru sýndar í töflu III. Alls höfðu 96,2\% sjúklinga sögu um reykingar, $67,6 \%$ reyktu fram að aðgerð og meðal pakkaárafjöldi var 42,1 ár. Tæpur priðjungur sjúklinganna (28\%) hafði sögu um langvinnan teppusjúkdóm í lungum, 26\% um kransæðasjúkdóm og 17\% um hjartsláttartruflanir. Um priðjungur sjúklinga hafði $\mathrm{FEV}_{1}$ gildi undir $80 \%$ af viðmiðunargildi. Flestir sjúklingar voru í
ASA flokkum 2 (43,2\%) og 3 (53,5\%).

Alls greindust 52 sjúklingar með fylgikvilla $(24,4 \%)$, par af 16 sjúklingar $(7,5 \%)$ með alvarlega og 36 (17\%) með minniháttar fylgikvilla (tafla IV). Tólf sjúklingar purftu enduraðgerð, sjö vegna blæðingar, tveir vegna fleiðruholssýkingar, aðrir tveir vegna æxlisvaxtar í skurðbrún og einn vegna berkjufleiðrufistils. Loftleki eftir aðgerð var algengur, í >4 daga hjá 23 sjúklingum (10,8\%) og í $>7$ daga hjá 45 sjúklingum (21,1\%).

Enginn sjúklingur lést innan 30 daga frá aðgerð (0\% skurðdauði). Tveir sjúklingar létust innan 90 daga eftir aðgerð, báðir með sögu um kransæðasjúkdóm og hjartsláttaróreglu. Annar fékk lungnabólgu í kjölfar aðgerðar og lést 36 dögum eftir aðgerð. Hinn lést úr heilablæðingu 75 dögum eftir aðgerð. Tveir sjúklingar $(0,9 \%)$ dóu í sömu sjúkrahúslegu (hospital mortality) en báđir voru með undirliggjandi kransæðasjúkdóm. Annar peirra lést úr lungnakrabbameini 92 dögum eftir aðgerð en hinn úr öndunar- og nýrnabilun 129 dögum eftir aðgerð.

Aðhvarfsgreining á áhættupáttum fylgikvilla sýndi að sjúklingar sem voru með hátt ASA gildi (OR 2,123, 95\% CI 1,204-3,764, p=0,009) og par sem aðgerð tók langan tíma (OR 1,008, 95\% CI 1,002-1,014, p=0,009), voru í marktækt aukinni áhættu að fá minniháttar fylgikvilla. Einnig sást tilhneiging til aukinnar áhættu hjá peim sem gengist höfðu undir blaðnám hægra megin (OR 1,830, 95\% CI 0,969-3,455, p=0,06). Eldri sjúklingar (OR 1,075, 95\% CI 1,008-1,147, p=0,03) voru í marktækt aukinni áhættu að fá meiriháttar fylgikvilla og tilhneiging sást hjá peim sem gengist höfðu undir tvíblaðnám (OR 4,098, 95\% CI 0,902-18,610, p=0,07) og höfðu langa reykingasögu (OR 1,021, 95\% CI 0,996-1,048, p=0,097).

\section{Umræður}

Pessi rannsókn sýnir að árangur blaðnámsaðgerða við lungnakrabbameini er góður hér á landi, en tíoni alvarlegra fylgikvilla var lág (7,5\%) og enginn sjúklingur lést innan 30 daga. Í öðrum rannsóknum hefur skurðdauði oftast verið á bilinu 0,6-4\%.9. 14-16 Fjórir sjúklingar létust í sömu sjúkrahúslegu og aðgerðin (sjúkrahúsdauði 1,9\%). Allir höfðu pessir sjúklingar sögu um hjartasjúkdóma og dánarorsakir peirra tengdust hjarta og/eða öndunarfærum.

Tíðni alvarlegra fylgikvilla reyndist sambærileg við erlendar rannsóknir9, 16 og mun lægri en í nýlegri íslenskri rannsókn á lungnabrottnámi. ${ }^{17}$ Með hækkandi aldri voru sjúklingar í aukinni hættu á að fá meiriháttar fylgikvilla og tilhneiging sást einnig hjá peim sem gengist höfðu undir 
tvíblaðnám og höfðu langa reykingasögu. Af alvarlegum fylgikvillum voru blæðingar algengastar $(3,3 \%)$ og blæddi mest 4 L. Oftast var blæðingin frá lungnaslagæð eða lungnabláæð og purftu sjö pessara sjúklinga að fara í enduraðgerð. Aðrir alvarlegir fylgikvillar voru hjarta- $(2,8 \%)$ og öndunarbilun $(1,9 \%)$ en aðeins einn sjúklingur greindist með berkjufleiðrufistil $(0,5 \%)$ sem er lægri tíðni en í öðrum rannsóknum. ${ }^{18-21}$

Tíðni minniháttar fylgikvilla er í flestum atriðum í samræmi við aðrar rannsóknir, ${ }^{9,} 22$ og voru gáttaflökt og lungnabólga meðal peirra algengustu. Aðhvarfsgreining sýndi að eldri sjúklingar og peir sem reykt höfðu lengi voru î aukinni áhættu á að fá minniháttar fylgikvilla. Einnig sást sterk tilhneiging til aukinnar tíðni fylgikvilla hjá peim sem gengist höfðu undir tvíblaðnám. Langvarandi loftleki (>7 daga) var algengasti fylgikvillinn, eða hjá 21,1\% sjúklinga. Petta er hátt hlutfall samanborið við $10-15 \%$ í erlendum rannsóknum, ${ }^{23,24}$ en hafa verður í huga að skilgreining á loftleka getur verið breytileg á milli rannsókna. Tíðni loftleka virðist pó lækka pegar leið á rannsóknartímabilið, hugsanlega með aukinni notkun heftibyssa við skiptingu lungans.

Reykingatengdir sjúkdómar voru oft til staðar hjá pessum sjúklingum enda allir nema átta með sögu um reykingar og meðal pakkaárafjöldi rúmlega 42 ár. Pví kemur ekki á óvart að fylgikvillar hafi oft tengst öndunarfærum og/ eða hjarta- og æðakerfi. Tíðni hjartasjúkdóma og langvinnra lungnasjúkdóma var líkt og í öðrum rannsóknum há (42\% og 28\%) og rúmur priðjungur sjúklinga mældust fyrir aðgerðina með $\mathrm{FEV}_{1}$ gildi undir $80 \%$ viðmiðunarmörkum. Í öðrum rannsóknum hefur verið sýnt fram á að skert lungnastarfsemi er einn sterkasti forspárpáttur fyrir lakari útkomu, bæði eftir blað- og lungnabrottnám. ${ }^{25,} 26$ Í okkar rannsókn reyndist $\mathrm{FEV}_{1}$ ekki marktækur áhættupáttur í aðhvarfsgreiningu, hvorki fyrir minniháttar né meiriháttar fylgkvilla. Ekki er augljós skýring á pessu en pess má geta að nokkuð sterk tengsl fundust við reykingasögu.

Loftleki er ekki flokkaður með alvarlegum fylgikvillum en eykur ópægindi fyrir sjúklinginn og kostnað við meðferð. Sennilega er há tíðni loftleka í pessari rannsókn helsta skýringin á löngum legutíma (miðgildi 10 dagar). Langur legutími skýrist ekki af dvöl á gjörgæsludeild. Flestum sjúklinganna var hægt að ná úr öndunarvél á skurðstofu og aðeins 14,5\% peirra purftu að dveljast á gjörgæslu eftir aðgerðina. Ljóst er að stytta parf legutíma pessara sjúklinga hér á landi og í pví sambandi rökrétt að beina sjónum að pví að lækka tíðni loftleka. Til pess
Tafla IV. Fylgikvillar hjá 213 sjúklingum sem gengust undir blađnám vegna lungnakrabbameins af ekkismáfrumugeró á Íslandi 1999-2008. Gefinn er upp fjöldi og \% í sviga, n (\%). Sjúklingar geta haft fleiri en einn fylgikvilla.

\begin{tabular}{lc}
\hline Minniháttar fylgikvillar & $36(17)$ \\
\hline Gáttaflökt & $13(6,1)$ \\
\hline Lungnabólga & $13(6,1)$ \\
\hline Sárasýking & $5(2,3)$ \\
\hline Lömun á raddbandataug & $5(2,3)$ \\
\hline Fleiðruholssýking & $3(1,4)$ \\
\hline Meiriháttar fylgikvillar & $16(7,5)$ \\
\hline Blæðing sem krefst & $7(3,3)$ \\
\hline enduraðgerðar & $6(2,8)$ \\
\hline Hjartabilun & $4(1,9)$ \\
\hline Öndunarbilun & $3(1,4)$ \\
\hline Hjartadrep & $1(0,5)$ \\
\hline Berkjufleiðrufistill & \\
\hline
\end{tabular}

eru ýmis ráð, til dæmis má nota í auknum mæli límefni og heftibyssur með styrktum heftilínum.

Á rannsóknartímabilinu sást aukning í fjölda blaðnámsaðgerða, og pótt aukningin hafi ekki verið marktæk sem hlutfall af öllum greindum lungnakrabbameinum öðrum en smáfrumukrabbameinum var greinileg tilhneiging til staðar, eða 16,2\% á fyrri og 20,3\% á síðari hluta pess $(p=0,07)$. Í erlendum rannsóknum hefur petta hlutfall verið í kringum $17 \%$ (bil $16,5-17,5 \%)$ fyrir allar skurðaðgerðir saman. ${ }^{27,}$ ${ }^{28}$ Okkar hlutfall er pví með hærra móti enda eru lungnabrottnámsaðgerðir og fleygskurðir ekki taldir með. Séu pessar aðgerðir teknar með má gera ráð fyrir að allt að $25 \%$ sjúklinga fari í aðgerð og stenst pað samanburð við stærri sjúkrahús í nágrannalöndum okkar. ${ }^{6}$ Í nýlegri rannsókn á lungnabrottnámsaðgerðum á Íslandi sást einnig fjölgun aðgerða á síðari hluta rannsóknartímabilsins. ${ }^{17}$ Par voru meðal annars nokkrir sjúklingar sem greindir voru eftir 2005 og fengið höfðu geisla- og lyfjameðferð fyrir aðgerð. Pannig var pess freistað að minnka æxli sem í upphafi voru talin óskurðtæk. Aðeins eitt slíkt tilfelli var í pessari rannsókn.

Tæplega tveir af hverjum premur sjúklingum greindust vegna einkenna par sem hósti, mæði og brjóstverkur voru algengustu einkennin. Hinir (40\%) greindust fyrir tilviljun og var langoftast um að ræða myndrannsóknir, aðallega tölvusneiðmyndir, sem gerðar voru vegna óskyldra kvartana og sjúkdóma. Tilviljanagreindu æxlin voru minni $(3,2 \mathrm{~cm})$ en pau sem greindust vegna einkenna $(4 \mathrm{~cm})$ og langflest á stigi I $(63,5 \%)$ eða II (17,6\%). Í erlendum rannsóknum er sjaldan 
gefið upp hlutfall tilviljanagreininga. Engu að síður verður $40 \%$ að teljast hátt hlutfall, til dæmis eru til erlendar rannsóknir sem sýna að 10\% allra lungnakrabbameina greinist fyrir tilviljun en pá eru einnig taldir með sjúklingar sem ekki gangast undir skurðaðgerð. ${ }^{29}$ Í blaðnámshópnum er valinn sjúklingahópur og pví viðbúið að hlutfall tilviljanagreindra sé hærra. Á næstu árum má gera ráð fyrir að tilviljanagreindum æxlum eigi eftir að fjölga með vaxandi notkun tölvusneiðmyndarannsókna. ${ }^{1}$

Styrkleiki pessarar rannsóknar er að hún tekur til allra tilfella af lungnakrabbameini sem greindust og voru meðhöndluð hjá heilli pjóð á 10 ára tímabili. Aðeins sex læknar framkvæmdu aðgerðirnar á sömu stofnun sem auðveldar gagnaöflun og skráningu upplýsinga. Par að auki var hægt að leita að sjúklingum í tveimur aðskildum skrám sem minnkar líkur á að einhver tilfelli hafi gleymst. Veikleiki rannsóknarinnar er hins vegar að hún er afturskyggn, slíkar rannsóknir geta verið ónákvæmar við mat á einkennum og fylgikvillum enda eingöngu stuðst við upplýsingar úr sjúkraskrám. Æskilegra væri að skrá slíka pætti með framsýnni rannsókn.

Niðurstöðurnar benda til pess að skammtímaárangur blaðnámsaðgerða við lungnakrabbameini á tímabilinu 1999-2008 sé góður hér á landi. Alvarlegir fylgikvillar í kjölfar blaðnáms eru sjaldgæfir en áhættan er aukin hjá eldri sjúklingum með langa reykingasögu og hátt ASA skor.

\section{Pakkir}

Pakkir fær Sveinn Friðrik Gunnlaugsson, tölfræðingur hjá Tölfræðimiðstöð Háskóla Íslands, fyrir hjálp við aðstoð við tölfræðiúrvinnslu og Martin Ingi Sigurðsson læknir og doktorsnemi sem aðstoðaði við aðhvarfsgreiningu á tíðni fylgikvilla. Einnig fær Gunnhildur Jóhannsdóttir skrifstofustjóri og starfsfólk í skjalageymslu Landspítala í Vesturhlíð pakkir fyrir öflun sjúkraskráa og starfsfólk Krabbameinsfélags Íslands fyrir aðstoð við leit að sjúklingum. Loks fær Ásgeir Alexandersson læknanemi pakkir fyrir yfirlestur og góðar ábendingar.

\section{Heimildir}

1. Guðbjartsson T, Smáradóttir A, Skúladóttir $\mathrm{H}$, et al. Lungnakrabbamein - yfirlitsgrein. Læknablaðið 2008; 94: 297-311.

2. www.krabbameinsskra.is

3. Scott WJ, Howington J, Movsas B, American College of Chest P. Treatment of stage II non-small cell lung cancer. Chest 2003;123(1 Suppl):188S-201S.

4. Reif MS, Socinski MA, Rivera MP. Evidence-based medicine in the treatment of non-small-cell lung cancer. Clin Chest Med 2000; 21: 107-20

5. Schuchert MJ, Luketich JD. Solitary sites of metastatic disease in non-small cell lung cancer. Curr Treat Options Oncol 2003; 4: $65-79$

6. Laroche $\mathrm{C}$, Wells $\mathrm{F}$, Coulden $\mathrm{R}$, et al. Improving surgical resection rate in lung cancer. Thorax 1998; 53: 445-9.

7. Nesbitt JC, Putnam JB Jr, Walsh GL, Roth JA, Mountain CF. Survival in early-stage non-small cell lung cancer. Ann Thorac Surg 1995; 60: 466-72.

8. Mountain CF. Revisions in the International System for Staging Lung Cancer. Chest 1997; 111: 1710-7.

9. Myrdal G, Gustafsson G, Lambe M, Horte LG, Stahle E. Outcome after lung cancer surgery. Factors predicting early mortality and major morbidity. Eur J Cardiothorac Surg 2001; 20: 694-9.

10. Duque JL, Ramos G, Castrodeza J, et al. Early complications in surgical treatment of lung cancer: a prospective, multicenter study. Ann Thorac Surg 1997; 63: 944-50.

11. Ginsberg RJ, Rubinstein LV. Randomized trial of lobectomy versus limited resection for T1 N0 non-small cell lung cancer. Lung Cancer Study Group. Ann Thorac Surg 1995; 60: 615-22.

12. Guðbjartsson T, Gyllstedt E, Pikwer A, Jonsson P. Early surgical results after pneumonectomy for non-small cell lung cancer are not affected by preoperative radiotherapy and chemotherapy. Ann Thorac Surg 2008; 86: 376-82.

13. Dripps RD, Lamont A, Eckenhoff JE, et al. Role of anesthesia in surgical mortality. JAMA 1961; 178: 261-6.

14. Kadri MA, Dussek JE. Survival and prognosis following resection of primary non small cell bronchogenic carcinoma. Eur J Cardiothorac Surg 1991; 5: 132-6.

15. Wada $H$, Nakamura $T$, Nakamoto $K$, Maeda $M$, Watanabe Y. Thirty-day operative mortality for thoracotomy in lung cancer. J Thorac Cardiovasc Surg 1998; 115: 70-3.

16. Harpole DH Jr, DeCamp MM Jr, Daley J, et al. Prognostic models of thirty-day mortality and morbidity after major pulmonary resection. J Thorac Cardiovasc Surg 1999; 117: 969-79.

17. Porsteinsson H. Árangur lungnabrottnámsaðgerða við lungnakrabbameini á Íslandi. In. Reykjavík; 2008.

18. Sirbu H, Busch T, Aleksic I, Schreiner W, Oster O, Dalichau $\mathrm{H}$. Bronchopleural fistula in the surgery of non-small cell lung cancer: incidence, risk factors, and management. Ann Thorac Cardiovasc Surg 2001; 7: 330-6.

19. Sonobe $M$, Nakagawa $M$, Ichinose M, Ikegami N, Nagasawa $\mathrm{M}$, Shindo T. Analysis of risk factors in bronchopleural fistula after pulmonary resection for primary lung cancer. Eur J Cardiothorac Surg 2000; 18: 519-23.

20. Asamura H, Naruke T, Tsuchiya R, Goya T, Kondo H, Suemasu K. Bronchopleural fistulas associated with lung cancer operations. Univariate and multivariate analysis of risk factors, management, and outcome. J Thorac Cardiovasc Surg 1992; 104: 1456-64

21. Nagahiro I, Aoe M, Sano Y, Date H, Andou A, Shimizu N. Bronchopleural fistula after lobectomy for lung cancer. Asian Cardiovasc Thorac Ann 2007; 15: 45-8.

22. Yano T, Yokoyama H, Fukuyama Y, Takai E, Mizutani K, Ichinose $Y$. The current status of postoperative complications and risk factors after a pulmonary resection for primary lung cancer. A multivariate analysis. Eur J Cardiothorac Surg 1997; 11: $445-9$

23. Stolz AJ, Schutzner J, Lischke R, Simonek J, Pafko P. Predictors of prolonged air leak following pulmonary lobectomy. Eur J Cardiothorac Surg 2005; 27: 334-6. 
24. Brunelli A, Monteverde M, Borri A, Salati M, Marasco RD, Fianchini A. Predictors of prolonged air leak after pulmonary lobectomy. Ann Thorac Surg 2004; 77: 1205-10.

25. British Thoracic S, Society of Cardiothoracic Surgeons of Great B, Ireland Working P. BTS guidelines: guidelines on the selection of patients with lung cancer for surgery. Thorax 2001; 56: 89-108.

26. Colice GL, Shafazand S, Griffin JP, Keenan R, Bolliger CT, American College of Chest P. Physiologic evaluation of the patient with lung cancer being considered for resectional surgery: ACCP evidenced-based clinical practice guidelines (2nd edition). Chest 2007; 132(3 Suppl):161S-177S.
27. Rostad H, Strand T-E, Naalsund A, Talleraas O, Norstein J. Lung cancer surgery: the first 60 days.: A population-based study. Eur J Cardio-Thoracic Surgery 2006; 29: 824-8.

28. Myrdal G, Lamberg K, Lambe M, Stahle E, Wagenius G, Holmberg L. Regional differences in treatment and outcome in non-small cell lung cancer: a population-based study (Sweden). Lung Cancer 2009; 63: 16-22.

29. Spiro SG, Gould MK, Colice GL, American College of Chest P. Initial evaluation of the patient with lung cancer: symptoms, signs, laboratory tests, and paraneoplastic syndromes: ACCP evidenced-based clinical practice guidelines (2nd edition). Chest 2007; 132(3 Suppl):149S-160S.

\section{Postoperative complications following lobectomy for lung cancer in Iceland during 1999-2008}

Objective: Non small cell lung cancer (NSCLC) is the second most common cancer in Iceland. We studied the indications and surgical outcome of lobectomy for NSCLC in Iceland.

Materials and methods: 213 consecutive patients underwent lobectomy for NSCLC between 1999 and 2008. Data on indications, histology, TNM-stage and complications were analysed, and logistic regression used to assess outcome predictors.

Results: The majority of patients (60\%) were referred because of symptoms, whereas $40 \%$ were asymptomatic. Adenocarcinoma (62\%) and squamous cell carcinoma (29\%) were the most frequent histological types. Operative staging showed that $59.6 \%$ of cases were stage I, $17.8 \%$ were stage II, $7 \%$ were stage IIIA and $14.6 \%$ were stage
IIIB or IV. Mediastinoscopy was performed in $13.6 \%$ of cases. Mean operative time was 128 min., operative bleeding $580 \mathrm{ml}$ and median hospital stay 10 days. Sixteen patients $(7.5 \%)$ had major complications and $36(17.5 \%)$ had minor complications, such as atrial fibrillation and pneumonia. Twelve patients required reoperation, most often due to bleeding, but two had empyema and one had a bronchopleural fistula. Older patients with high ASA scores and extensive smoking history were at increased risk for complications. No patient died within 30 days of surgery whereas two $(0,9 \%)$ died within 90 days of surgery. Conclusions: The results of lobectomy for NSCLC in Iceland are excellent in relation to operative mortality and short term complications.

Skuladottir R, Oskarsdottir GN, Isaksson HJ, Jonsson J, Thorsteinsson H, Gudbjartsson T.

Postoperative complications following lobectomy for lung cancer in Iceland during 1999-2008. Icel Med J 2010; 96: $243-9$.

Key words: Lung cancer, lobectomy, surgery, indications, complications, operative mortality.

Correspondence: Tómas Guðbjartsson, tomasgud@landspitali.is

Barst: 4. október 2009, - sampykkt til birtingar: 25. janúar 2010 